CZASOPISMO INŻYNIERII LĄDOWEJ, ŚRODOWISKA I ARCHITEKTURY JOURNAL OF CIVIL ENGINEERING, ENVIRONMENT AND ARCHITECTURE

JCEEA, t. XXXIV, z. 64 (1/17), styczeń-marzec 2017, s. 407-422, DOI:10.7862/rb.2017.37

Mateusz RAJCHEL ${ }^{1}$

Tomasz SIWOWSKI ${ }^{2}$

\title{
ANALIZA NUMERYCZNA I BADANIA POD OBCIAŻENIEM MOSTU DROGOWEGO Z KOMPOZYTÓW FRP
}

\begin{abstract}
W pracy przedstawiono analizę numeryczną MES oraz wyniki badań statycznych i dynamicznych pierwszego polskiego mostu drogowego z kompozytów FRP. Analitycznie i doświadczalnie oceniono sztywność przęsła mostu i wytężenie jego głównych elementów, a także rozkład obciążenia ruchomego na poszczególne dźwigary oraz zachowanie konstrukcji pod obciążeniem dynamicznym. W obliczeniach MES zastosowano powłokowo - bryłowy model numeryczny przęsła mostu. W badaniach mostu mierzono przemieszczenia, odkształcenia i przyspieszenia wybranych elementów mostu pod próbnym obciążeniem statycznym i dynamicznym. Przeprowadzone badania wykazały odpowiednią nośność i sztywność przęsła mostu oraz potwierdziły jego właściwą charakterystykę dynamiczną. Główne wyniki badań mostu były zgodne z wynikami analizy numerycznej MES, co potwierdza poprawność modelu obliczeniowego, przyjętego na etapie projektowania mostu.
\end{abstract}

Słowa kluczowe: kompozyt FRP, most drogowy, analiza MES, badania mostu, walidacja modelu numerycznego

\section{Wprowadzenie}

Kompozyty włókniste FRP (ang. fibre reinforced polymer) w ciągu ostatnich lat stają się coraz powszechniej akceptowane i stosowane w budownictwie mostowym jako podstawowy materiał konstrukcyjny [9]. Kompozyty FRP charakteryzują się bardzo wysoką wytrzymałością, doskonałą trwałością, dużą sztywnością (kompozyty węglowe), niskimi kosztami utrzymania (LCCA), możliwością prefabrykacji oraz małym ciężarem, umożliwiającym szybkie i łatwe wznoszenie mostów. Dzięki zastosowaniu bardzo wytrzymałych, lekkich i odpornych na korozję kompozytów FRP jest możliwe uzyskanie wysokich nośno-

\footnotetext{
1 Autor do korespondencji / corresponding author: Mateusz Rajchel, Politechnika Rzeszowska, al. Powstańców Warszawy 12, 35-959 Rzeszów, (17) 8651 016, mrajchel@prz.edu.pl

2 Tomasz Siwowski, Politechnika Rzeszowska, al. Powstańców Warszawy 12, 35-959 Rzeszów, (17) 8651 596, siwowski@prz.edu.pl
} 
ści, trwałości i niezawodności obiektów mostowych. Do podstawowych wad konstrukcji kompozytowych w mostach należą: mała sztywność (w przypadku kompozytów szklanych) oraz nagła i krucha postać zniszczenia, bez objawów uplastycznienia [9]. Prowadzone w ostatnich latach badania wykazały, że efektywniejsze wykorzystanie kompozytów FRP jest możliwe w systemach hybrydowych, tj. przy zastosowaniu kompozytów FRP we współpracy z betonem [1]. Cienkościenny, najczęściej skrzynkowy kompozytowy dźwigar główny współpracuje $\mathrm{w}$ takim systemie $\mathrm{z}$ betonową płytą pomostu. Ważnymi w zastosowaniach mostowych cechami takich dźwigarów hybrydowych są: duża sztywność bez konieczności stosowania drogich włókien węglowych oraz korzystna dla bezpieczeństwa obiektu, pseudoplastyczna postać zniszczenia [4].

Jednym z głównych celów projektu badawczego pn. Com-Bridge (www.com-bridge.pl), finansowanego przez NCBiR w ramach programu $D e-$ monstrator + była budowa pełnowymiarowego mostu drogowego z kompozytów FRP o parametrach użytkowych wymaganych przepisami dla obiektu mostowego w ciągu drogi publicznej. W ramach projektu wykonano m.in. analizę numeryczną MES przęsła mostu o konstrukcji hybrydowej oraz kompleksowe badania mostu pod próbnym obciążeniem statycznym i dynamicznym. Analitycznie i doświadczalnie oceniono sztywność i nośność głównych elementów przęsła, rozkład obciążenia ruchomego na poszczególne dźwigary oraz zachowanie konstrukcji pod obciążeniem dynamicznym. W pracy przedstawiono przestrzenny model numeryczny przęsła wraz z głównymi wynikami analizy MES oraz ocenę zachowania się mostu pod obciążeniem statycznym i dynamicznym. Porównano także wyniki analizy numerycznej z wynikami badań eksperymentalnych, dokonując oceny i walidacji modelu numerycznego. Walidowany model numeryczny został wykorzystany w kolejnych projektach mostów hybrydowych.

\section{Opis ogólny mostu}

Pierwszy polski most drogowy z kompozytów FRP został zbudowany w miejscowości Błażowa k. Rzeszowa nad rzeką Ryjak [8]. Most jest obiektem jednoprzęsłowym, swobodnie podpartym (rys.1). Konstrukcję przęsła tworzy ustrój płytowo-belkowy o następujących głównych parametrach technicznych:

- nośność: klasa B wg normy PN-85/S-10030, tj. pojazdy o ciężarze 40 ton,

- rozpiętość teoretyczna przęsła: 21,00 m,

- długość całkowita mostu: 22,30 m,

- szerokość całkowita pomostu: 10,54 m,

- szerokości użytkowe pomostu: jezdnia $7 \mathrm{~m}(2 \times 3,5 \mathrm{~m})$, opaski bezpieczeństwa $2 \times 0,50 \mathrm{~m}$, chodnik jednostronny $1,50 \mathrm{~m}$, bariera z gzymsem $2 \times 0,52 \mathrm{~m}$;

- wysokość konstrukcyjna przęsła: 1,20 m.

Przęsło mostu jest zbudowane $\mathrm{z}$ czterech kompozytowych dźwigarów skrzynkowych, zespolonych z płytą pomostu z betonu lekkiego LC 35/38, zbrojoną prętami kompozytowymi GFRP (ang. glass fibre reinforced polymer). 


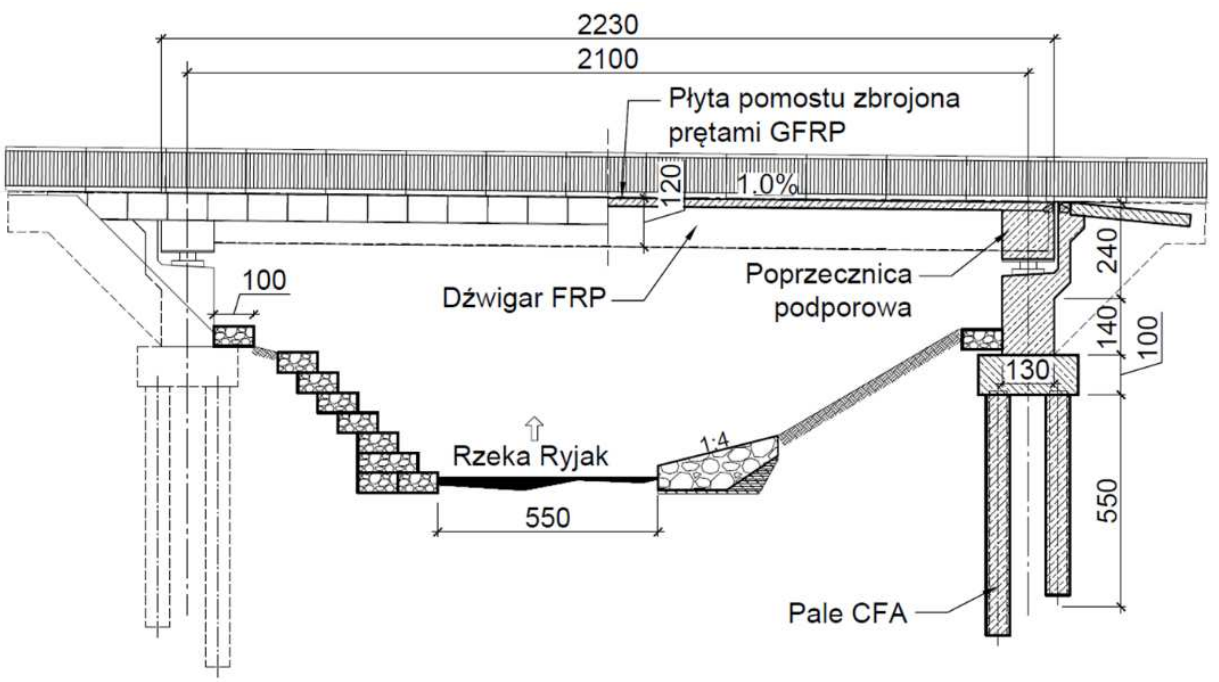

Rys. 1. Widok z boku i przekrój podłużny mostu

Fig. 1. Side view and longitudinal section of the bridge

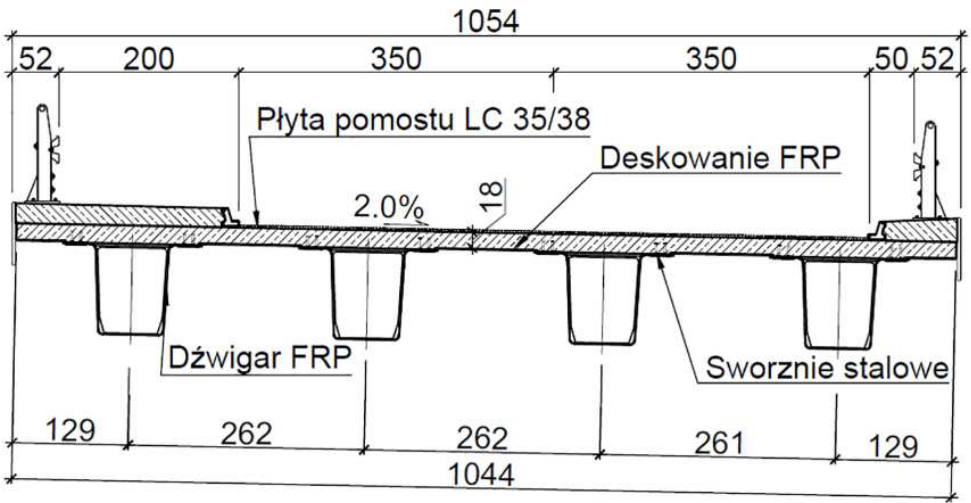

Rys. 2. Przekrój poprzeczny przęsła mostu

Fig. 2. Cross-section of bridge span

Dźwigary kompozytowe mają wysokość $1,02 \mathrm{~m}$ i zmienną szerokość od $0,62 \mathrm{~m}$ w poziomie pasa dolnego do $1,55 \mathrm{~m} \mathrm{w}$ poziomie pasów górnych (rys.2). Płyta pomostu jest zespolona $\mathrm{z}$ dźwigarami za pomocą galwanizowanych sworzni stalowych o średnicy $20 \mathrm{~mm}$ oraz kleju epoksydowego. Wyposażenie przęsła składa się z kap chodnikowych z betonu lekkiego LC 30/33, konwencjonalnej nawierzchni i izolacji, odwodnienia, urządzeń dylatacyjnych oraz barier. Podpory mostu wykonano w postaci żelbetowych przyczółków pełnościennych, posadowionych na palach wierconych o średnicy $0,6 \mathrm{~m}$ i długości $8,0 \mathrm{~m}$, formowanych w gruncie. Każdy przyczółek jest posadowiony na 10 palach. 
Korpusy dźwigarów wykonano z naprzemiennie ułożonych tkanin szklanych i węglowych oraz z pianki PVC (ang. polyvinyl chloride) wypełniającej środniki (rys.3). Dźwigary są usztywnione dwunastoma wewnętrznymi przeponami o konstrukcji warstwowej, umieszczonymi w zmiennym rozstawie $1,45-2,20 \mathrm{~m}$. Wszystkie elementy kompozytowe dźwigarów wykonano w technologii VARTM (ang. vacuum assisted resin transfer moulding) na bazie żywicy epoksydowej.
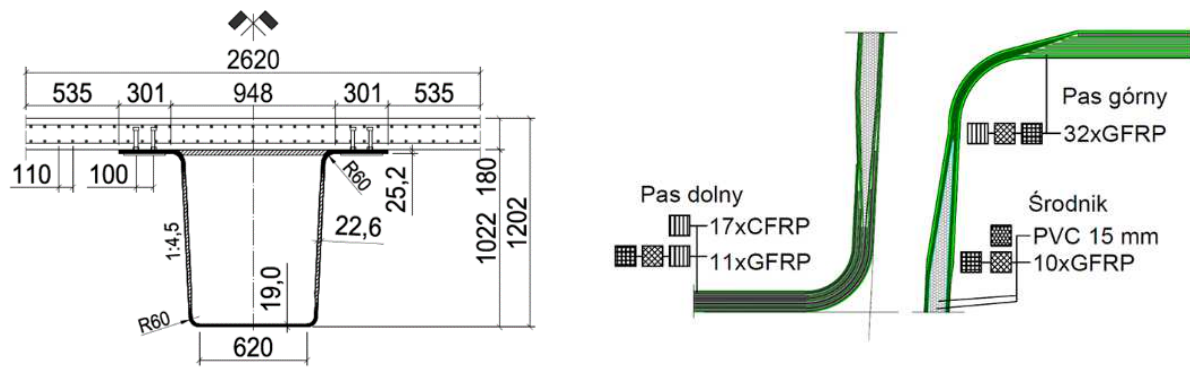

Rys. 3. Przekrój poprzeczny oraz konstrukcja dźwigara FRP

Fig. 3. Cross-section and the structure of FRP girder

Płyta pomostu o stałej grubości $0,18 \mathrm{~m}$ jest wykonana $\mathrm{z}$ betonu lekkiego klasy LC 35/38, zbrojonego dwiema siatkami z prętów kompozytowych GFRP o średnicy $12 \mathrm{~mm}$. W strefach podporowych dźwigary kompozytowe są dodatkowo stężone dwiema poprzecznicami betonowymi, wykonanymi monolitycznie $\mathrm{z}$ płytą pomostu $\mathrm{z}$ betonu lekkiego.

\section{Analiza numeryczna MES przęsła mostu}

\subsection{Model numeryczny przęsła i jego obciążenie}

Model numeryczny przęsła mostu utworzono w środowisku MES wykorzystując system Sofistik 2014 (rys.4). Analizę prowadzono w przestrzeni trójwymiarowej (p3) za pomocą elementów powierzchniowych (e2) i bryłowych (e3). Wszystkim elementom powierzchniowym o wymiarach $0,30 \times 0,40 \mathrm{~m}$ (tzw. aspect ratio 0,75 ) oraz bryłowym o wymiarach $0,18 \times 0,40 \mathrm{~m}$ (aspect ratio 0,45 ) nadano grubości zgodne $\mathrm{z}$ wymiarami projektowymi poszczególnych elementów przęsła. W elementach powierzchniowych kompozytów zamodelowano ich warstwy zgodnie z zaprojektowaną budową poszczególnych części dźwigara. Parametry materiałowe dla poszczególnych elementów skończonych, wyznaczone na podstawie badań materiałowych, przyjęto wg tabeli 1 . 

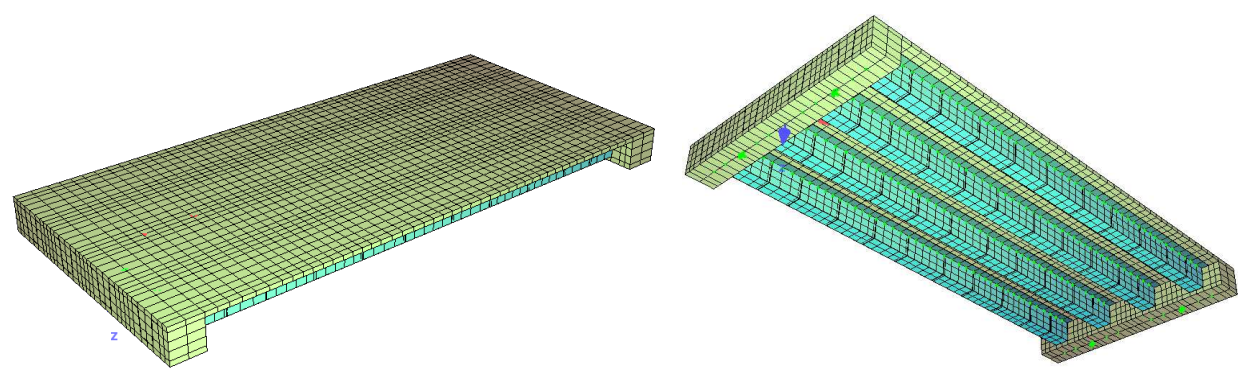

Rys. 4. Wizualizacja modelu numerycznego MES przęsła mostu

Fig. 4. Visualization of the FEM numerical model of bridge span

Tabela 1. Parametry materiałowe (w głównych osiach materiałowych)

Table 1. The material parameters (in the main material axis)

\begin{tabular}{|c|c|c|c|c|c|c|c|c|}
\hline \multirow[t]{2}{*}{ 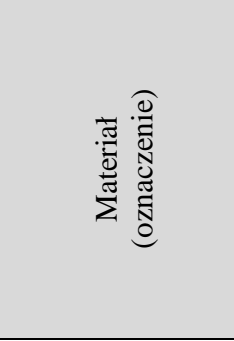 } & \multirow{2}{*}{ 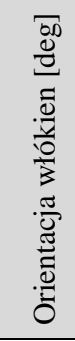 } & \multicolumn{2}{|c|}{ 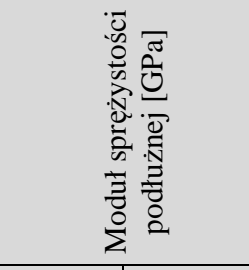 } & \multicolumn{2}{|c|}{ 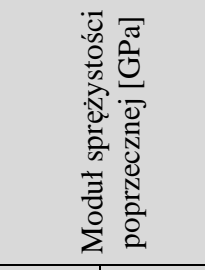 } & \multicolumn{2}{|c|}{ 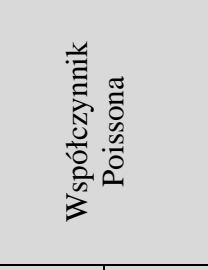 } & \multirow{2}{*}{ 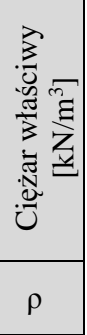 } \\
\hline & & $\mathrm{E}_{1}$ & $\mathrm{E}_{2}$ & $\mathrm{G}_{12}$ & $\begin{array}{c}\mathrm{G}_{23}= \\
\mathrm{G}_{13}\end{array}$ & $v_{12}$ & $v_{21}$ & \\
\hline $\begin{array}{l}\text { Laminat szklany } \\
1200 \mathrm{~g} / \mathrm{m}^{2}\end{array}$ & $0 / 90$ & 20,50 & 20,50 & 3,90 & 3,04 & 0,019 & 0,019 & 18,0 \\
\hline $\begin{array}{l}\text { Laminat szklany } \\
1200 \mathrm{~g} / \mathrm{m}^{2}\end{array}$ & 0 & 42,13 & 10,87 & 4,40 & 2,71 & 0,29 & 0,075 & 18,0 \\
\hline $\begin{array}{l}\text { Laminat szklany } \\
800 \mathrm{~g} / \mathrm{m}^{2}\end{array}$ & $0 / 90$ & 20,00 & 20,00 & 3,90 & 2,83 & 0,029 & 0,029 & 18,0 \\
\hline $\begin{array}{l}\text { Laminat węglo- } \\
\text { wy } 600 \mathrm{~g} / \mathrm{m}^{2}\end{array}$ & 0 & 115,76 & 5,72 & 4,00 & 3,32 & 0,41 & 0,021 & 16 \\
\hline Pianka PVC & - & - & - & 0,027 & 0,027 & 0,4 & 0,4 & 0,8 \\
\hline Beton LC35/38 & - & 21,562 & 21,562 & 8,98 & 8,98 & 0,2 & 0,2 & 19,7 \\
\hline Pręty GFRP & - & 57,8 & - & - & - & 0,19 & - & - \\
\hline
\end{tabular}

Obciążenie przęsła $\mathrm{w}$ analizie numerycznej przyjęto zgodnie $\mathrm{z}$ docelowo zrealizowanymi schematami ustawienia pojazdów obciążających podczas badań mostu (rys.6). Powierzchnia kontaktu koła przednich i tylnych osi pojazdów obciążających wyniosła odpowiednio $0,2 \times 0,3 \mathrm{~m}$ oraz $0,2 \times 0,6 \mathrm{~m}$. Równomierne obciążenie powierzchniowe o tej geometrii zostało przyłożone do elementów bryłowych (e3) symulujących betonową płytę pomostową. 


\subsection{Wyniki obliczeń MES}

Obliczone w analizie numerycznej MES wartości ugięć i odkształceń dźwigarów w przekroju miarodajnym w środku rozpiętości przęsła przedstawiono w tabelach 2 i 3.

Tabela 2. Wartości ugięć dźwigarów w środku rozpiętości przęsła wg analizy MES

Table 2. FEM's values of girder's vertical deflections at midspan

\begin{tabular}{|c|c|c|c|c|}
\hline \multicolumn{5}{|c|}{ Obciążenia niesymetryczne } \\
\hline \multirow{2}{*}{$\begin{array}{c}\text { Schemat } \\
\text { obciążenia }\end{array}$} & \multicolumn{4}{|c|}{ Wartość ugięcia dźwigara [mm] } \\
\hline & 1 - skrajny & 2 - środkowy & 3 - środkowy & 4 - skrajny \\
\hline S1a & 15,79 & 21,25 & 25,64 & 23,55 \\
\hline S2a & 30,20 & 24,47 & 17,81 & 14,01 \\
\hline S3a & 27,41 & 22,25 & 16,24 & 12,85 \\
\hline \multicolumn{5}{|c|}{ Obciążenia symetryczne } \\
\hline \multirow{2}{*}{$\begin{array}{c}\text { Schemat } \\
\text { obciążenia }\end{array}$} & \multicolumn{4}{|c|}{ Wartość ugięcia dźwigara [mm] } \\
\hline & 1 - skrajny & 2 - środkowy & 3 - środkowy & 4 - skrajny \\
\hline S1b & 39,34 & 46,89 & 46,89 & 39,34 \\
\hline S2b & 49,19 & 48,90 & 41,98 & 32,60 \\
\hline S3b & 44,71 & 44,47 & 38,24 & 29,81 \\
\hline
\end{tabular}

Tabela 3. Odkształcenia podłużne pasa dolnego w środku rozpiętości przęsła wg analizy MES

Table 3. FEM's longitudinal strains in girder's bottom flanges at midspan

\begin{tabular}{|c|c|c|c|c|}
\hline \multicolumn{5}{|c|}{ Obciążenia niesymetryczne } \\
\hline \multirow{2}{*}{$\begin{array}{c}\text { Schemat } \\
\text { obciążenia }\end{array}$} & 1 - skrajny & 2 - środkowy & 3 - środkowy & 4 - skrajny \\
\cline { 2 - 5 } & 0,310 & 0,412 & 0,489 & 0,456 \\
\hline S1a & 0,579 & 0,472 & 0,347 & 0,276 \\
\hline S2a & 0,533 & 0,432 & 0,317 & 0,254 \\
\hline S3a & \multicolumn{5}{|c|}{ Obciążenia symetryczne } \\
\hline \multicolumn{5}{|c|}{ Wartość odkształcenia pasa dolnego dźwigara [\%o] } \\
\hline $\begin{array}{c}\text { Schemat } \\
\text { obciążenia }\end{array}$ & 1 - skrajny & 2 - środkowy & 3 - środkowy & 4 - skrajny \\
\hline S1b & 0,766 & 0,900 & 0,900 & 0,766 \\
\hline S2b & 0,949 & 0,935 & 0,811 & 0,639 \\
\hline S3b & 0,871 & 0,865 & 0,744 & 0,586 \\
\hline
\end{tabular}

Wykorzystując model numeryczny przęsła odczytano także częstotliwości drgań własnych konstrukcji. W programie obliczeniowym Sofistik wyznaczono częstotliwości i postacie drgać własnych za pomocą iteracyjnej metody Lanczosa. Częstotliwości drgań własnych dla dwóch pierwszych postaci drgań giętych przęsła wyniosły odpowiednio 3,09 Hz oraz 5,26 Hz (rys.5). 

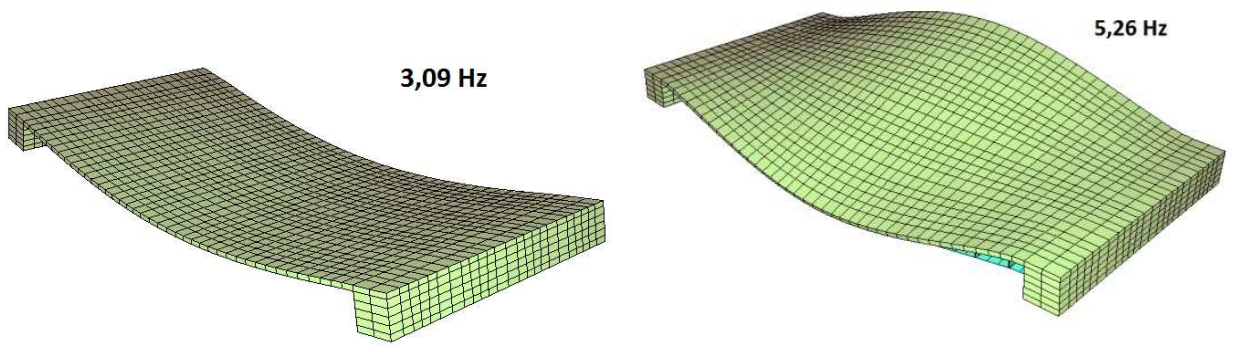

Rys. 5. Pierwsza (z lewej) oraz druga (z prawej) postać i częstotliwość drgań własnych przęsła

Fig. 5. Eigen frequency for the first (left) and the second (right) form of span vibrations

\subsection{Rozdział poprzeczny obciążenia}

Współczynniki rozdziału poprzecznego obciążeń ruchomych LDF (ang. load distribution factor) są stosowane do obliczania wielkości obciążeń ruchomych, przypadających na poszczególne dźwigary przęsła mostu. Na podstawie wartości ugięć (tabela 2) oraz odkształceń (tabela 3) pasa dolnego dźwigara w środku rozpiętości przęsła wyznaczono współczynniki rozdziału poprzecznego obciążenia wg wzoru (1) [5]:

$$
\mathrm{LDT}=\frac{\Delta U_{i}}{\sum_{i=1}^{n} \Delta U_{i}}
$$

gdzie:

$\Delta U_{i}$ - całkowite zweryfikowane ugięcie lub odkształcenie rozpatrywanego pasa dolnego dźwigara , $i$;

$\sum_{i=1}^{n} \Delta U_{i}$ - suma całkowitych zweryfikowanych ugięć lub odkształceń „n” pasów dolnych dźwigara.

Tabela 4. Współczynniki LDF obliczone na podstawie ugięć wg MES

Table 4. FEM's load distribution factors calculated on the basis of defections

\begin{tabular}{|c|c|c|c|c|}
\hline \multirow{5}{*}{ Obciążenie niesymetryczne } \\
\hline \multirow{2}{*}{$\begin{array}{c}\text { Schemat } \\
\text { obciążenia }\end{array}$} & \multicolumn{5}{|c|}{ Wartość współczynnika LDF - obciążenie niesymetryczne [-] } \\
\cline { 2 - 5 } & 1 - skrajny & 2 - środkowy & 3 - środkowy & 4 - skrajny \\
\hline S1a & 0,183 & 0,246 & 0,297 & 0,273 \\
\hline S2a & 0,349 & 0,283 & 0,206 & 0,162 \\
\hline S3a & 0,348 & 0,283 & 0,206 & 0,163 \\
\hline \multicolumn{5}{|c|}{ Obciążenie symetryczne } \\
\hline \multirow{2}{*}{$\begin{array}{c}\text { Schemat } \\
\text { obciążenia }\end{array}$} & 1 - Skrajny & 2 - środkowy & 3 - środkowy & 4 - skrajny \\
\cline { 2 - 5 } & 0,228 & 0,272 & 0,272 & 0,228 \\
\hline S1b & 0,285 & 0,283 & 0,243 & 0,189 \\
\hline S2b & 0,284 & 0,283 & 0,243 & 0,190 \\
\hline S3b & \multicolumn{4}{c}{} \\
\hline
\end{tabular}


Wartości współczynników rozdziału poprzecznego obciążenia dla każdego dźwigara, obliczonych na podstawie wyznaczonych numerycznie ugięć i odkształceń, przedstawiono w tabeli 4 i 5 odpowiednio pod obciążeniem niesymetrycznym (schematy S1a, S2a, S3a) i symetrycznym (schematy S1b, S2b, S3b). Zaznaczono także wielkości maksymalne dla dźwigara skrajnego i środkowego.

Tabela 5. Współczynniki LDF wg MES obliczone na podstawie odkształceń

Table 5. FEM's load distribution factors calculated on the basis of strains

\begin{tabular}{|c|c|c|c|c|}
\hline \multicolumn{5}{|c|}{ Obciążenie niesymetryczne } \\
\hline \multirow{2}{*}{$\begin{array}{c}\text { Schemat } \\
\text { obciążenia }\end{array}$} & \multicolumn{4}{|c|}{ Wartość współczynnika LDF - obciążenie niesymetryczne [-] } \\
\hline & 1 - skrajny & 2 - środkowy & 3 - środkowy & 4 - skrajny \\
\hline S1a & 0,186 & 0,247 & 0,293 & 0,274 \\
\hline S2a & 0,346 & 0,282 & 0,207 & 0,165 \\
\hline S3a & 0,347 & 0,281 & 0,206 & 0,165 \\
\hline \multicolumn{5}{|c|}{ Obciążenie symetryczne } \\
\hline \multirow{2}{*}{$\begin{array}{c}\text { Schemat } \\
\text { obciążenia }\end{array}$} & \multicolumn{4}{|c|}{ Wartość współczynnika LDF - obciążenie niesymetryczne [-] } \\
\hline & 1 - skrajny & 2 - środkowy & 3 - środkowy & 4 - skrajny \\
\hline S1b & 0,230 & 0,270 & 0,270 & 0,230 \\
\hline S2b & 0,285 & 0,280 & 0,243 & 0,192 \\
\hline S3b & 0,284 & 0,282 & 0,243 & 0,191 \\
\hline
\end{tabular}

\section{Badania mostu pod próbnym obciążeniem}

\subsection{Schematy obciążeń i układ pomiarowy}

Badania mostu pod próbnym obciążeniem statycznym i dynamicznym przeprowadzono w grudnia 2015 r. jako badania odbiorcze przed dopuszczeniem mostu do eksploatacji [8]. Do badań statycznych mostu użyto czterech czteroosiowych samochodów ciężarowych, każdy o całkowitej masie z ładunkiem 32,08 ton. Łączna masa czterech pojazdów wyniosła 128,3 tony. Badania statyczne przeprowadzono dla sześciu schematów ustawienia pojazdów (oznaczenia schematów: a - pojazdy 1-2, b - pojazdy 1-4) (rys. 6). Badania dynamiczne mostu zrealizowano przy użyciu dwóch samochodów z ładunkiem poruszających się po obiekcie odpowiednio z prędkościami 10, 30 i $50 \mathrm{~km} / \mathrm{h}$. Wzmocnienie efektu dynamicznego uzyskano poprzez zastosowanie wymuszonego hamowania oraz przejazd przez próg o wysokości $5 \mathrm{~cm}$, ułożony prostopadle do osi jezdni.

Podczas badań statycznych mierzono przemieszczenia pionowe dźwigarów, odkształcenia kompozytów dźwigarów i betonu pomostu, przemieszczenia łożysk oraz osiadania podpór. Podczas badań dynamicznych rejestrowano czasowe zmiany wartości przemieszczeń $w$ dwóch dźwigarach w środku ich rozpiętości oraz przyspieszenia $\mathrm{w}$ kilku punktach przęsła umieszczonych na pomoście (rys.7). Przemieszczenia mierzono przy pomocy czujników indukcyjnych o bazie pomiarowej $50 \mathrm{~mm}$ i dokładności odczytu $0,01 \mathrm{~mm}$, połączonych ze wzmacniaczem i systemem akwizycji danych firmy HBM. Przyśpieszenia mierzono czujnikami akcelerometrycznymi. 

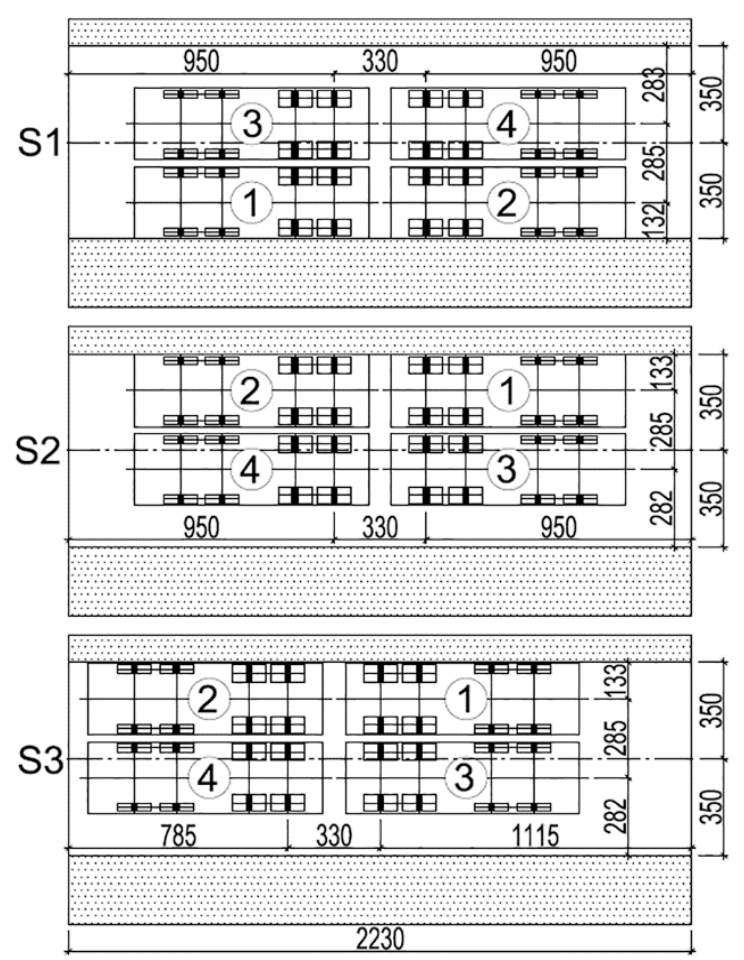

Rys. 6. Ustawienie pojazdów obciążających w schematach $\mathrm{S} 1, \mathrm{~S} 2, \mathrm{~S} 3$

Fig. 6. Load test configuration in schemes S1, S2, S3
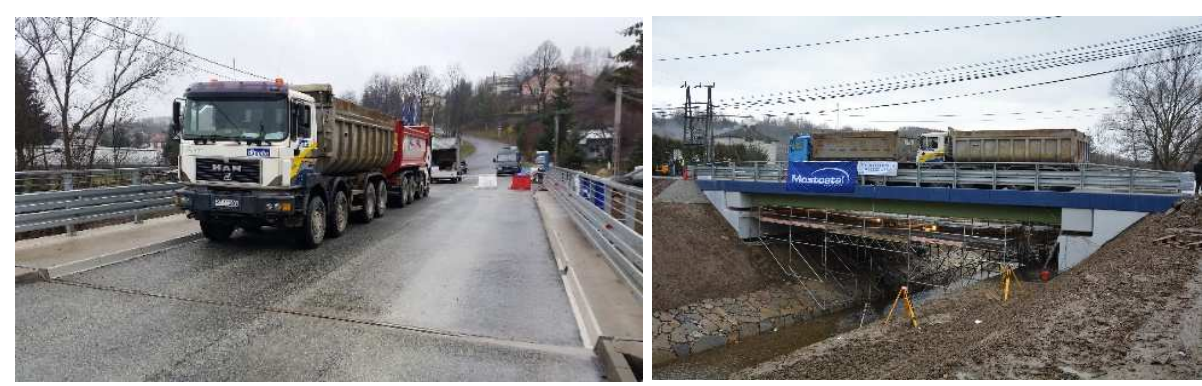

Rys. 7. Próbne obciążenie mostu i stanowisko pomiaru przemieszczeń

Fig. 7. Proof testing of the bridge and set-up of displacement measurement

\subsection{Wybrane wyniki pomiarów}

W tabelach 6 i 7 przedstawiono wartości ugięć dźwigarów i odkształceń kompozytu w środku szerokości pasa dolnego w przekroju środkowym przęsła. Ugięcia i odkształcenia wyznaczono dla obciążeń niesymetrycznych (schemat obciążenia S1-3 a) oraz symetrycznych (schemat obciążenia S1-3 b). 
Tabela 6. Wartości ugięć w środku rozpiętości przęsła

Table 6. Vertical deflections at midspan

\begin{tabular}{|c|c|c|c|c|}
\hline \multicolumn{5}{|c|}{ Obciążenie niesymetryczne } \\
\hline \multirow{2}{*}{$\begin{array}{c}\text { Schemat } \\
\text { obciążenia }\end{array}$} & 1 - skrajny & 2 - środkóś ugięcia dźwigara [mm] & 3 - środkowy & 4 - skrajny \\
\cline { 2 - 5 } & 6,30 & 10,60 & 13,70 & 11,30 \\
\hline S1a & 17,95 & 14,35 & 9,15 & 5,95 \\
\hline S2a & 16,40 & 13,10 & 8,30 & 5,40 \\
\hline S3a & \multicolumn{5}{|c|}{ Obciążenie symetryczne } \\
\hline \multicolumn{5}{|c|}{ Wartość ugięcia dźwigara [mm] } \\
\hline \multirow{2}{*}{$\begin{array}{c}\text { Schemat } \\
\text { obciążenia }\end{array}$} & 1 - skrajny & 2 - środkowy & 3 - środkowy & 4 - skrajny \\
\cline { 2 - 5 } S1b & 21,35 & 27,65 & 26,45 & 19,35 \\
\hline S2b & 28,80 & 30,00 & 23,70 & 15,20 \\
\hline S3b & 25,60 & 26,40 & 21,05 & 13,55 \\
\hline
\end{tabular}

Tabela 7. Odkształcenia podłużne na środku pasa dolnego w środku rozpiętości przęsła Table 7. Longitudinal strain at midspan in the bottom flange

\begin{tabular}{|c|c|c|c|c|}
\hline \multicolumn{5}{|c|}{ Obciążenie niesymetryczne } \\
\hline \multirow{2}{*}{$\begin{array}{c}\text { Schemat } \\
\text { obciążenia }\end{array}$} & 1 - skrajny & 2 - środkowy & 3 - środkowy & 4 - skrajny \\
\hline & 0,134 & 0,196 & 0,279 & 0,250 \\
\hline S1a & 0,425 & 0,272 & 0,189 & 0,121 \\
\hline S2a & 0,397 & 0,256 & 0,176 & 0,110 \\
\hline S3a & \multicolumn{5}{|c|}{ Obciążenie symetryczne } \\
\hline \multicolumn{5}{|c|}{ Wartość odkształcenia pasa dolnego dźwigara [\%o] } \\
\hline $\begin{array}{c}\text { Schemat } \\
\text { obciążenia }\end{array}$ & 1 - skrajny & 2 - środkowy & 3 - środkowy & 4 - skrajny \\
\cline { 2 - 5 } S1b & 0,487 & 0,528 & 0,579 & 0,433 \\
\hline S2b & 0,670 & 0,566 & 0,506 & 0,328 \\
\hline S3b & 0,608 & 0,508 & 0,450 & 0,291 \\
\hline
\end{tabular}

Podstawowa zidentyfikowana podczas badań częstotliwość drgań własnych przęsła wyniosła $3,98 \mathrm{~Hz}$ i została wyznaczona na podstawie czasowych zmian wartości przemieszczeń w środku rozpiętości przęsła podczas badań dynamicznych mostu.

\subsection{Rozdział poprzeczny obciążenia jako wynik badania mostu}

Na podstawie wartości ugięć (tabela 6) i odkształceń (tabela 7) w środku pasa dolnego dźwigarów w przekroju miarodajnym w środku rozpiętości przęsła wyznaczono współczynniki rozdziału poprzecznego obciążenia LDF wg wzoru (1), które przedstawiono w tabeli 8 i 9. 
Tabela 8. Współczynniki LDF obliczone na podstawie pomierzonych ugięć

Table 8. Load distribution factors calculated on the basis of measured defection

\begin{tabular}{|c|c|c|c|c|}
\hline \multicolumn{5}{|c|}{ Obciążenie niesymetryczne } \\
\hline \multirow{2}{*}{$\begin{array}{c}\text { Schemat } \\
\text { obciążenia }\end{array}$} & \multicolumn{2}{|c|}{ Wartość współczynnika LDF - obciążenie niesymetryczne [-] } \\
\cline { 2 - 5 } & 1 - skrajny & 2 - środkowy & 3 - środkowy & 4 - skrajny \\
\hline S1a & 0,150 & 0,253 & 0,327 & 0,270 \\
\hline S2a & 0,379 & 0,303 & 0,193 & 0,192 \\
\hline S3a & 0,380 & 0,303 & 0,192 & 0,125 \\
\hline \multicolumn{5}{|c|}{ Obciążenie symetryczne } \\
\hline \multirow{2}{*}{$\begin{array}{c}\text { Schemat } \\
\text { obciążenia }\end{array}$} & 1 - Skrajny & 2 - środkowy & 3 - środkowy & 4 - skrajny \\
\cline { 2 - 5 } S1b & 0,225 & 0,292 & 0,279 & 0,204 \\
\hline S2b & 0,295 & 0,307 & 0,243 & 0,156 \\
\hline S3b & 0,296 & 0,305 & 0,243 & 0,156 \\
\hline
\end{tabular}

Tabela 9. Współczynniki LDF obliczone na podstawie pomierzonych odkształceń kompozytu

Table 9. Load distribution factors calculated on the basis of measured composite strains

\begin{tabular}{|c|c|c|c|c|}
\hline \multicolumn{5}{|c|}{ Obciążenie niesymetryczne } \\
\hline \multirow{2}{*}{$\begin{array}{c}\text { Schemat } \\
\text { obciążenia }\end{array}$} & Wartość współczynnika LDF - obciążenie niesymetryczne [-] \\
\cline { 2 - 5 } & 1 - skrajny & 2 - środkowy & 3 - środkowy & 4 - skrajny \\
\hline S1a & 0,156 & 0,228 & 0,325 & 0,291 \\
\hline S2a & 0,422 & 0,270 & 0,188 & 0,120 \\
\hline S3a & 0,423 & 0,273 & 0,187 & 0,117 \\
\hline \multicolumn{5}{|c|}{ Obciążenie symetryczne } \\
\hline \multirow{2}{*}{$\begin{array}{c}\text { Schemat } \\
\text { obciążenia }\end{array}$} & Wartość współczynnika LDF - obciążenie niesymetryczne [-] \\
\cline { 2 - 5 } & 1 - skrajny & 2 - środkowy & 3 - środkowy & 4 - skrajny \\
\hline S1b & 0,240 & 0,260 & 0,286 & 0,214 \\
\hline S2b & 0,324 & 0,273 & 0,244 & 0,158 \\
\hline S3b & 0,327 & 0,274 & 0,242 & 0,157 \\
\hline
\end{tabular}

\section{Porównanie obliczeń teoretycznych z wynikami badań}

\subsection{Ugięcia}

Porównanie wyników pomiarów ugięć (przemieszczeń pionowych) dźwigarów głównych w środku rozpiętości przęsła $\mathrm{z}$ wartościami teoretycznymi oraz wartością dopuszczalną przedstawiono na rys. 8. Na podstawie wytycznych projektowych mostu $[2,3]$ dopuszczalną wartość ugięcia przęsła przyjęto jako L/300 czyli 70,0 mm. Maksymalne pomierzone ugięcie sprężyste dźwigara pod maksymalnym obciążeniem symetrycznym (128,3 tony) wyniosło $30,0 \mathrm{~mm}$ (L/700), co stanowi $61 \%$ wartości ugięcia teoretycznego $(48,90 \mathrm{~mm})$ i jest o $43 \%$ mniejsze od wartości ugięcia dopuszczalnego $(70 \mathrm{~mm})$. Ugięcie pod maksymalnym obciążeniem asymetrycznym (64,2 tony) wyniosło $17,95 \mathrm{~mm}$. Wyznaczona na tej podstawie sztywność podłużna konstrukcji mostu jako proporcja siły obciążającej do powstałego od niej ugięcia wyniosła $\mathbf{k}=\mathbf{3 5 , 7} \mathbf{k N} / \mathbf{m m}$. 
Jak pokazały badania przęsło mostu kompozytowego w zakresie rozpiętości ok. 21,0 m jest znacznie bardziej podatne w stosunku do konstrukcji betonowych czy zespolonych stalowo-betonowych, których sztywność jest na poziomie 100 $\mathrm{kN} / \mathrm{mm}[6]$.

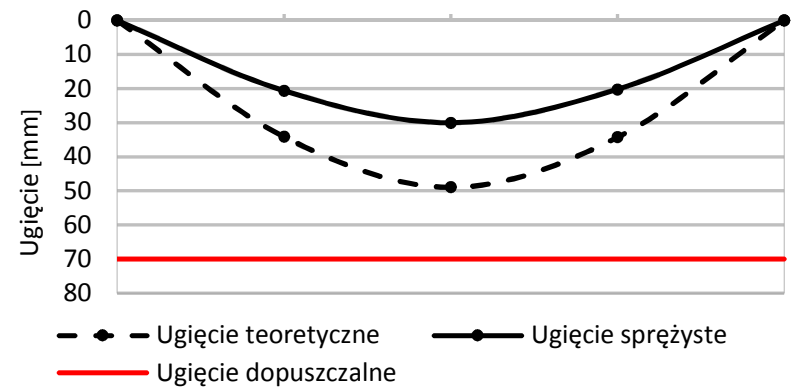

Rys. 8. Porównanie rzeczywistych ugięć sprężystych do wartości teoretycznych i dopuszczalnej

Fig. 8. Comparison of measured elastic deflections with theoretical and allowable ones

\subsection{Odkształcenia kompozytu FRP}

Maksymalne odkształcenie sprężyste kompozytu wystąpiło w pasie dolnym i wyniosło $0,670 \%$. Odkształcenie to stanowi $71 \%$ wartości odkształcenia teoretycznego równego 0,949\%o. Graniczne wartości charakterystyczne odkształceń rozciągających uzyskane $\mathrm{z}$ badań materiałowych (w układzie globalnym x,y w kierunku osi podłużnej dźwigara) warstw kompozytowych, składających się na laminat FRP pasa dolnego wynoszą:

- 9,93\%o - jednokierunkowa warstwa węglowa o orientacji włókien $0^{\circ}$ względem osi podłużnej dźwigara.

- $10,54 \%$ - dwukierunkowa warstwa szklana o orientacji włókien $+/-45^{\circ}$ względem osi podłużnej dźwigara.

Pomierzone wartości odkształceń kompozytu FRP pasa dolego stanowią odpowiednio $6,75 \%$ i $6,36 \%$ wartości odkształceń granicznych warstwy węglowej $(9,93 \%$ ) i szklanej $(10,54 \% o)$.

\subsection{Rozdział poprzeczny obciążenia ruchomego}

Porównanie teoretycznego i rzeczywistego rozdziału poprzecznego obciążenia w środku rozpiętości przęsła na podstawie ugięć (tabela 4 i 8) oraz odkształceń (tabela 5 i 9) przedstawiono odpowiednio na rys. 9 i 10.

Dla dźwigara skrajnego maksymalna rzeczywista wartość LDF wyniosła $\mathbf{0 , 3 8 0}$ (na podstawie ugięć) oraz $\mathbf{0 , 4 2 3}$ (na podstawie odkształceń). Współczynniki te stanowią odpowiednio $109 \%$ oraz $122 \%$ wartości teoretycznej, równej 0,349 (na podstawie ugięć i odkształceń). Dla dźwigara środkowego rzeczywista wartość LDF wyniosła $\mathbf{0 , 3 0 7}$ (na podstawie ugięć) oraz $\mathbf{0 , 2 8 6}$ (na podstawie od- 
kształceń). Współczynniki te stanowią odpowiednio $109 \%$ oraz $101 \%$ wartości teoretycznej równej 0,282 (na podstawie ugięć i odkształceń).
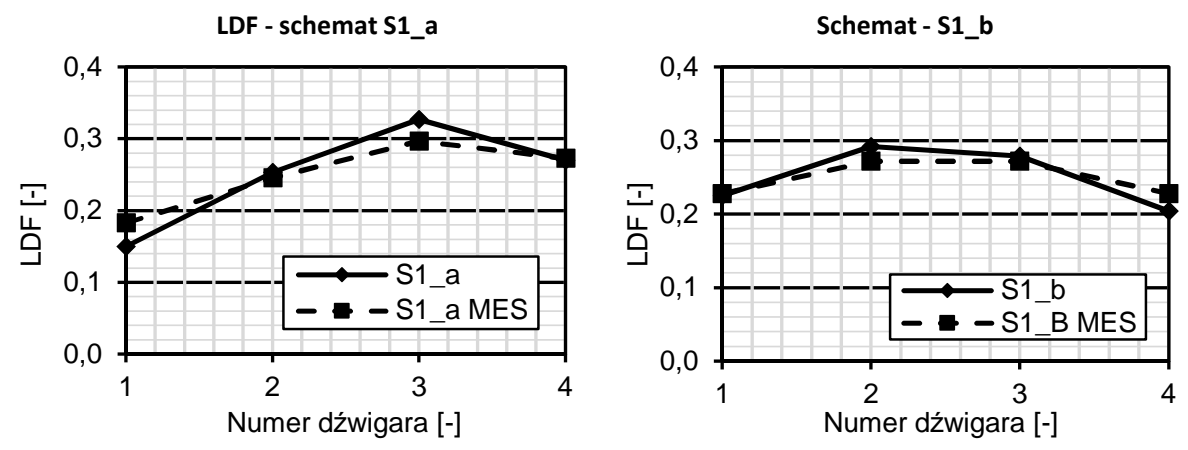

LDF - schemat S2 a
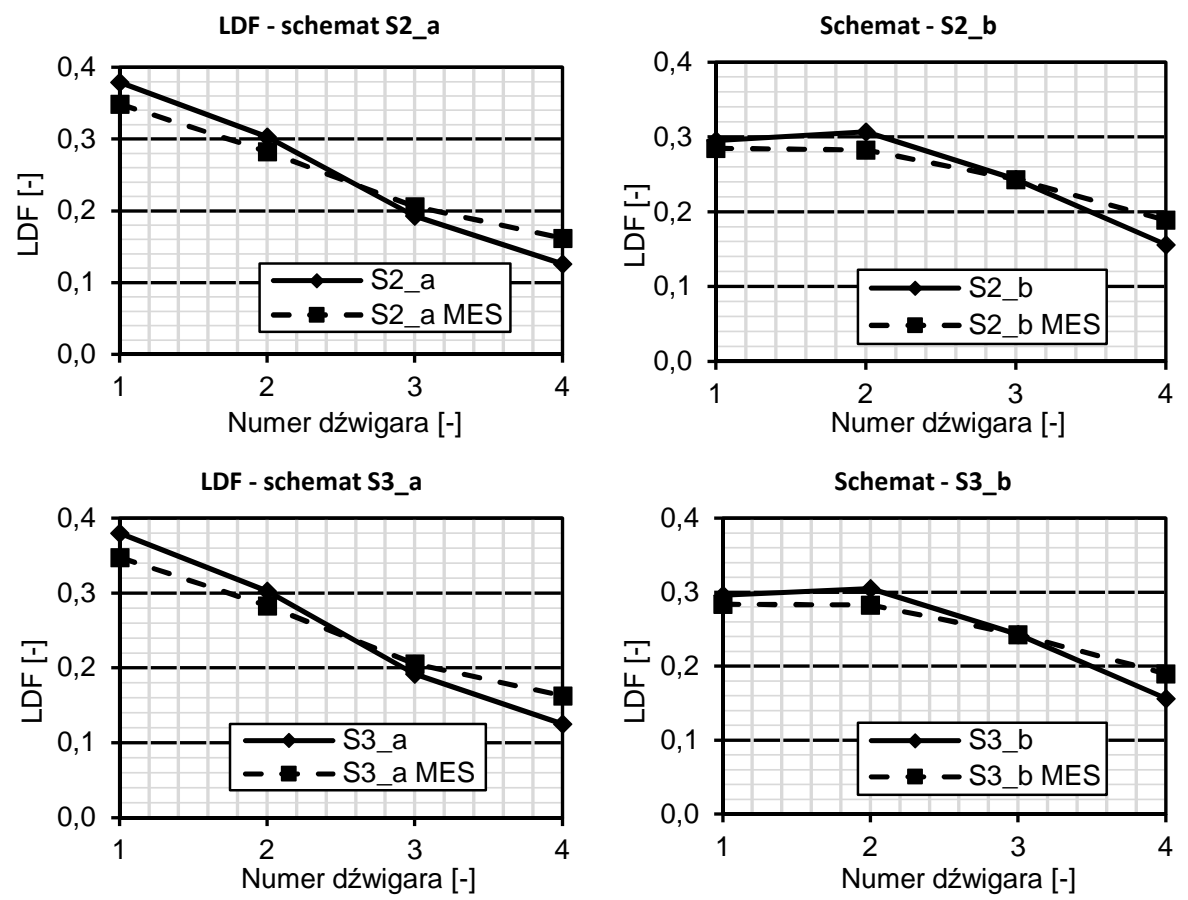

Rys. 9. Porównanie teoretycznego i rzeczywistego rozdziału poprzecznego obciążenia dla obciążeń niesymetrycznych (z lewej) i symetrycznych (z prawej) na podstawie ugięć

Fig. 9. Comparison of theoretical and experimental load distribution for asymmetric (left) and symmetrical (right) loads schemes based on deflections 

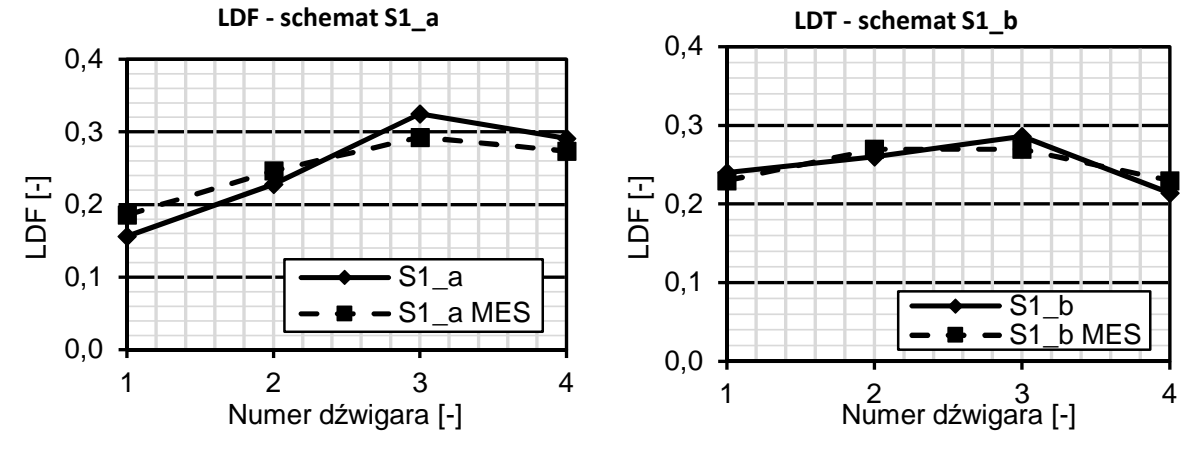

LDF - schemat S2_a
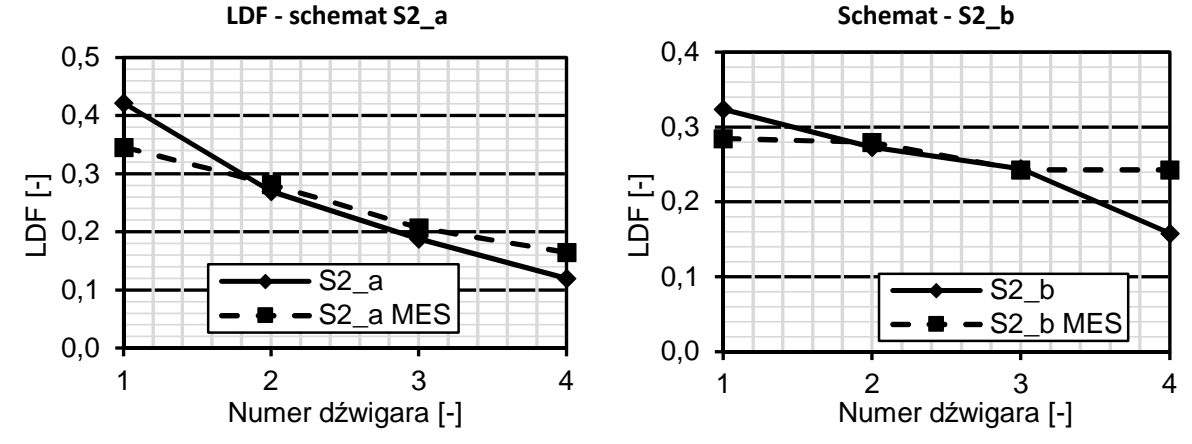

LDF - schemat S3 a
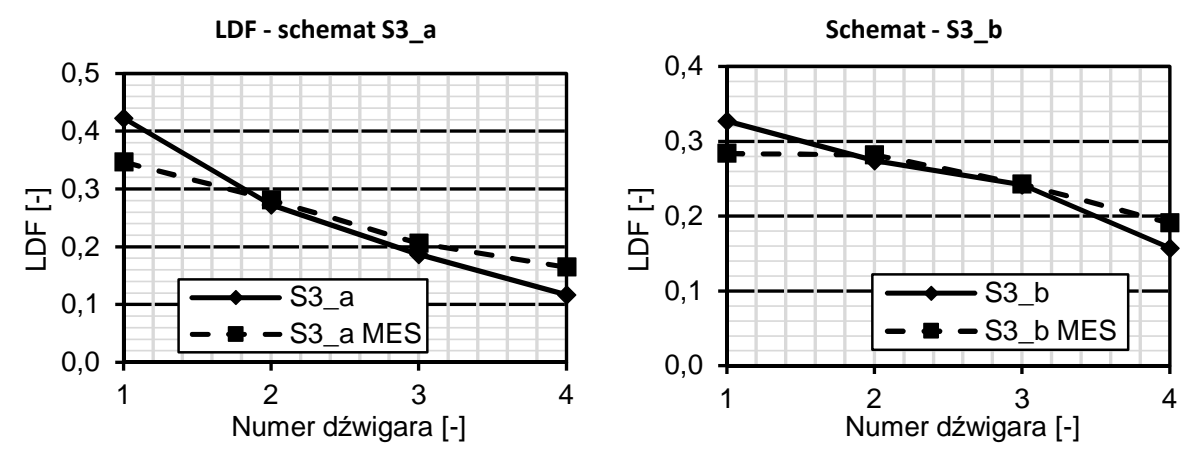

Rys. 10. Porównanie teoretycznego i rzeczywistego rozdziału poprzecznego obciążenia dla obciążeń niesymetrycznych (z lewej) i symetrycznych (z prawej) na podstawie odkształceń kompozytu

Fig. 10. Comparison of theoretical and experimental load distribution for asymmetric (left) and symmetrical (right) loads schemes based on FRP strains

Różnice w wartościach LDF pomiędzy pomiarami ugięć i odkształceń były na poziomie $11,3 \%$ oraz $7,3 \%$ odpowiednio dla dźwigara skrajnego i środkowego. Porównanie pomierzonych wartości LDF z wartościami teoretycznymi (obliczonymi) wykazało różnice w zakresie od 1 do $22 \%$. Większe wartości LDF zostały uzyskane z pomiarów na moście. 


\subsection{Częstotliwość drgań własnych}

Zidentyfikowana pierwsza częstotliwość drgań własnych wyniosła $3,98 \mathrm{~Hz}$ i jest większa od wartości wyznaczonej numerycznie $(3,09 \mathrm{~Hz})$ o $29 \%$. Wartość rzeczywista częstotliwości jest także większa od minimalnej wartości zalecanej w rozporządzeniu [7], równej $3 \mathrm{~Hz}$. Cechą charakterystyczną badanego przęsła mostu o rozpiętości 21,0 m jest stosunkowo niska częstotliwość drgań własnych, która jest spowodowana jego małą sztywnością $\mathbf{k}$ [6].

\section{Podsumowanie}

Głównym celem badań statycznych i dynamicznych mostu drogowego z kompozytów FRP było sprawdzenie jego zachowania pod obciążeniem w stosunku do dopuszczalnych parametrów eksploatacyjnych oraz walidacja modelu numerycznego przęsła mostu, który został zastosowany do obliczeń wytężenia i sztywności w różnych konfiguracjach obciążeniowych na etapie projektowania.

Uzyskane na podstawie badań wartości przemieszczeń, odkształceń i częstości drgań własnych mostu były mniejsze od wartości granicznych, dopuszczalnych wg właściwych zaleceń i wytycznych [2] [3], [7], co potwierdziło odpowiednią nośność, sztywność oraz zachowanie konstrukcji mostu pod obciążeniem dynamicznym.

Walidację modelu numerycznego przeprowadzono na podstawie porównania ugięć i odkształceń otrzymanych dla każdego dźwigara w poziomie pasa dolnego. Na postawie tych porównań stwierdzono zgodność tych wartości na poziomie od $61 \%$ do $99 \%$ w zależności od analizowanego przekroju mostu. Wysoka zgodność modelu MES z wynikami badań dotyczyła także rozdziału poprzecznego obciążenia oraz częstotliwości drgań własnych. Maksymalna różnica pomiędzy wynikami badań i obliczeń dla LDF była na poziomie $22 \%$ dla dźwigara skrajnego oraz $9 \%$ dla dźwigara środkowego. W przypadku częstotliwości drgań własnych przęsła różnica wynosiła $29 \%$.

Na podstawie otrzymanych wyników można uznać, że model numeryczny MES bardzo dobrze odzwierciedla zachowanie przęsła mostu w przekroju poprzecznym oraz pod obciążeniem dynamicznym oraz mniej zadowalająco w rozkładzie na długości mostu. Główną przyczyną niezgodności tych wyników, głównie w zakresie przemieszczeń pionowych dźwigarów, jest brak odwzorowania w modelu MES przęsła współpracujących deskowań płyty pomostu oraz wyposażenia mostu, w tym głównie sztywnych kap chodnikowych, balustrad, poręczy, itp. Kolejną przyczyną niezgodności może być sposób odwzorowania w modelu MES rzeczywistej budowy kompozytów FRP, złożonych z kilkudziesięciu warstw o różnych parametrach. W zastosowanym modelu przęsła do opisu kompozytów FRP wykorzystano model materiału o parametrach zastępczych (zbiorczych).

Analiza numeryczna i badania mostu zostały zrealizowane w ramach projektu R\&D pn.: „Com-Bridge - Innowacyjny most drogowy z kompozytów FRP”, współfinansowanego przez Narodowe Centrum Badań i Rozwoju w ramach Przedsięwzięcia Pilotażowego „Wsparcie badań naukowych i prac rozwojowych $w$ skali demonstracyjnej DEMONSTRATOR+"(umowa nr UOD-DEM-1-041-/001). 


\section{Literatura}

[1] Chen Y., P. H. Ziehl, K. W. Harrison. 2009. Experimental characterization and optimization of hybrid FRP/RC bridge superstructure system. Journal of Bridge Engineering 14: 45-54.

[2] Design Manual for Roads and Bridges (DMRB). Volume 1, Section 3, Part 17: DB 9/05 - Design of FRP Bridges and Highways Agency, Scottish Executive, Welsh Assembly Government, The Department for Regional Development Northern Ireland, May 2005.

[3] JRC Science for Policy Report. Prospect for new guidance in the design on FRP. Support to the implementation, harmonization and failure development of the Eurocodes. 2016.

[4] Kitane Y., A. Aref. 2004. Static and fatigue testing of hybrid fiber-reinforced polymer - concrete bridge superstructure. Journal of Composites for Construction 8: 182-190.

[5] Machelski $C z$. 2014. Parameters of load transverse distribution across bridge. Road and Bridges 13: 131-143.

[6] Machelski Cz. 2016. Sztywność obiektu mostowego jako parametru użytkowego konstrukcji inżynierskich. Przegląd Komunikacyjny 2: 37-32.

[7] Rozporządzenie Ministra Transportu i Gospodarki Morskiej z dnia 30 maja 2000 r. w sprawie warunków technicznych, jakim powinny odpowiadać obiekty inżynierskie i ich usytuowanie (Dz. U. Nr 63/00, poz. 735).

[8] Siwowski T., Rajchel M., Kaleta D., Wtasak L. 2016. Pierwszy polski most drogowy z kompozytów FRP. Mosty 2: 62-66.

[9] Zoghi M. 2014. The international Handbook of FRP Composites in Civil Engineering. Boca Raton. CRC Press, Taylor \& Francis Group LLC.

\section{THE FEM ANALYSIS AND PROOF LOAD TEST OF A ROAD BRIDGE MADE OF FRP COMPOSITES}

\section{S u m m a r y}

The first Polish road bridge made of FRP composites and its FEM analysis as well as the behaviour under static and dynamic proof tests have been presented in the paper. The theoretical and experimentally determined stiffness and strength of the hybrid FRP - concrete span, load distribution factors and dynamic behaviour have been compared. The detailed shell - brick numerical model of the real bridge has been used for FEM theoretical analysis. During the proof tests the girder's deflection, FRP and concrete strains and span accelerations have been measured. The proof load tests have revealed the sufficient carrying capacity and good transverse and longitudinal stiffness as well as the proper dynamic behaviour of the bridge. Moreover the FEM model of the span has been quite well validated against the measured results. FEM analysis and proof tests confirmed that FRP composite as the modern and innovative structural material can be widely utilised in bridge construction as an alternative to common materials as steel and concrete.

Keywords: road bridge, FRP composite, FEM analysis, proof test, model validation

Przestano do redakcji: 09.02.2017 $r$.

Przyjęto do druku: 31.03.2017 r. 